\title{
The importance of central places in the socio- economic migration patterns of hunter gatherers in Asele Lappmark
}

\begin{abstract}
Several levels of central places are described in relation to local bands, regional bands and tribes. Various levels of social and economic structure have a corresponding central place- the winter village or ritual places for bands and tribes. Local centres like winter villages supported subsistence redistribution and possessed various resources. Centres between bands and tribes are rich in resources during a limited time and help to exploit marginal resources. From an ecological point of view one can predict where optimal central places are located when economic structure and land use patterns are known. Rivers and eskers, as means of communication, are important determinants. Watershed areas, as means of conceptualizing land areas, can be used to estimate boreal forest hunters' land divisions in household units, similar to the historically known forest Saami household land use units (lappskatteland). In Åsele Lappmark several clusters of settlements have been recorded mainly indicating winter central places or base camps. Through the period $6000 \mathrm{BP}$ to $500 \mathrm{BP}$ different migration models have been applied to the cluster pattern revealing how the pattern has evolved.
\end{abstract}

Volume I Issue 6 - 2017

\author{
Lars Goran Spang \\ Department of Archeology, Umeå University, Sweden
}

Correspondence: Lars Goran Spang, department of Archeology, Umeå University, Sweden, Email lgspang@gmail.com

Received: August 18,2017| Published:September 15, 2017

\section{Introduction}

Studies concerning the types and functions of central places are usually analyzed in conjunction with societies that are highly stratified or in other words centralized. Thus, is there any reason to analyze central place functions in decentralized societies or in connection with egalitarian bands? I believe that the problem is equally interesting for the understanding of hunter gatherers as it is for the understanding of empires. All structures imply the existence of one or more centers that play an important role, which in turn implies that unstructured societies can hardly exist. Centers can be said to be nodes that hold together a system or structure. They can be found to function on several different levels within any given system.

I was faced with the issue of centralization among hunter gatherers for the first time at a conference in Trondheim. ${ }^{1}$ My contribution to the conference then became a basis for my dissertation. The subject has been discussed in several contexts since then, but I think there are still aspects that need to be expanded upon. ${ }^{1}$ This article is a rework of a chapter in my thesis and it will also be the basis for an in-depth study of the subject by means of simulation methods. ${ }^{2}$

The classification of centers in any particular society depends on the theoretical basis used in analyzing these structures. I prefer to highlight the social and economic aspects of central places. Economic centers can be instituted in response to the distribution of resources and economic requirements. Economic needs grow in conjunction with specialization and the exploitation of marginal areas. The social aspects of central places are especially noticeable in sparsely populated areas were an extensive economy is practiced which consists of a contact network involving hundreds of people that is maintained through fixed and agreed upon meeting places. ${ }^{2}$

${ }^{1}$ An overview of current aspects on hunter gatherers is found in Cummings et. al. 2014.

${ }^{2}$ Several suitable simulation methods are presented in Barceló \& Castillo 2016.
For a subsistence economy the base camp may provide a sufficiently centralized place for a local band. Here resources are routinely distributed on an everyday bases within a household and between households. Base camps of this type are located at the intersection between the various territories of the different households and/or local bands. This daily contact between households and/or local bands creates and sustains a vibrant group dynamic.

On a higher level there is a need for one or more central place to hold together a regional band consisting of 10-20 households. Such nodes could be maintained through rituals at certain seasons and places. Gatherings of 50-100 people at such an event for a short period of time need not be a major strain on the local environment. The need for a network that binds together the members of a regional band is motivated primarily in order to acquire and distribute necessary resources of a more specialized nature such as craft products and rare commodities, etc. When some resources are only available in marginal areas, such as slate, asbestos and other rare minerals, a symbiosis between the center and the periphery develops. From a social point of view, the composition of the groups can change with e.g. marriages, even if the primary purpose of the center is the distribution of rare commodities and products. ${ }^{3}$

A common center for a band of about 500 people would require significantly greater resources in order to support it. Such a large group would also demand a corresponding organizational form that could manage the distribution of resources. Places such as salmon jumps and other localities with temporary yet rich concentrations of foodstuffs are a prerequisite for the location of a center for an entire tribe. The need for a central place of this magnitude can hardly be explained by the need to distribute subsistence goods or specialized articles. The need for such centers should be explained in terms of ritual and social cohesion, primarily in order to maintain contacts with other tribes. Consequently, a feature of such centers should be

${ }^{3}$ For further discussions along this line see Whallon 2006 
that they are at the intersection of tribal areas. Economic reasons for central places of this type in Åsele Lappmark could be, for example, the trade in bronze and iron.

\section{Ethnology as an analytic tool form of social organization in the boreal zone and contact networks among hunter gatherers}

Ethnographic comparisons are of course important for suggesting ways in which hunting areas are utilized and how communication between households and bands is maintained. Such studies have been done before, but not primarily to understand what types of centers there are and how they have evolved. Instead these studies have focused on population distribution and land $\mathrm{use}^{3}$ and the types of settlement patterns that can be deduced from the archaeological data. ${ }^{4}$ North American examples have played a major part in these studies. ${ }^{5,6}$ North American ethnographic examples have been used to highlight issues of land utilization in the Kemi Lappmark in Finland ${ }^{7}$ and land use by the Sáme in northern Scandinavia. ${ }^{8}$ Athol Anderson's comparison of the Canadian fur trade and prehistoric hunting in northern Sweden is also an important contribution. ${ }^{9}$

Ethnographic analogies from North America are widely used while studies from neighboring Eurasia are not. This of course has to do with language difficulties. Another unfortunate fact is that ethnographic comparisons are often limited to the study of individual systems and not systems that are interacting with each other. To get an idea of the role of centers in the hunter gatherer communities we need to see how societies work in relation to each other.

Ethnographic studies can be used to estimate the size of an area a hunter gatherer household needs for their subsistence. The results can then be used to model how a group of households interact in relation to a central village, for example a Sáme Siida, a winter residence or whatever type of central place that is under study. Under certain circumstances any socio-economic system may become isolated, but the archaeological record undoubtedly demonstrates that most systems and social groups have been in contact with each other in some way. A few authors have studied multi group or system dynamics. ${ }^{10,11}$ Contacts of this kind should be supplemented by an analysis concerning the function of central places. Such an analysis will be attempted here using materials from Åsele Lappmark, an area that is archaeologically well investigated in comparison with other areas in northern Sweden. It is also a geographically and historically demarcated and documented area of long standing.

\section{Eco-geography as an analytic tool, eco- geological conditions that promote the establishment of central places}

Neolithic winter base camps consisting of one or more subterranean houses are always located near flowing water and on well drained soils. Easy access to wildlife is also a perquisite as shown by the fact that pitfalls are found concentrated in the same areas. Their location at a confluence between rivers is also striking. Advantages in communication could be an explanation, but there are also hunting benefits. Branching rivers form a funnel that direct wildlife towards the confluence. These geographic characteristics attract many other types of settlements besides winter dwellings. Ethnographic comparisons show that the carrying capacity of the local environment should be able to provide for the subsistence needs of the group and that fishing is thus a good reserve in that regard. Other and perhaps less obvious criterion is that the site should provide a good view over an area, usually a lake and that there is therefore a hill nearby that provides protection against the wind and which can be used as a lookout point. One factor less noted is how the members of a group or society orientate themselves and navigate the landscape, factors which will also determine where a meeting or central place is located. It is common among cultural geographers to reason thus and underscores the significance of waterways and terrestrial formations for the establishment and development of central places. Similar conditions apply to hunter gatherer communities as well (Figure 1).

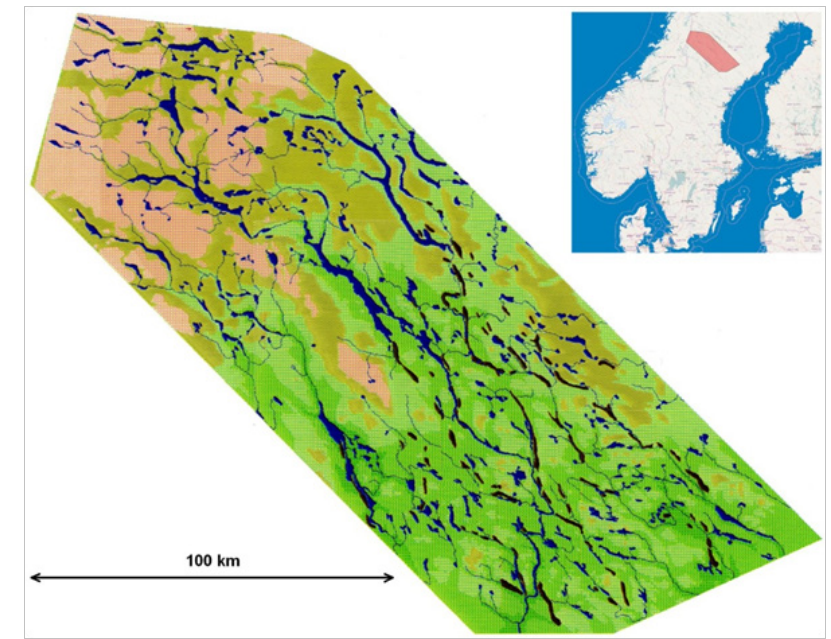

Figure I Åsele Lappmark. Elevation contours are at intervals of 100 meters. Eskers are colored brown.

Orientation or navigational methods determine how roads and paths are established. In Norrland and the interior of boreal forest areas in general, watercourses are an obvious means of orientation. In similar fashion eskers, in particular those in Åsele Lappmark, have functioned as lines of communication. Territories are agreements between households and bands concerning the distribution of land and thus must, of course, be delimited according to how the territories are conceptualized. Consequently, using watercourses as means of orientation, a watershed or system, becomes the unit designated as a territory. Ørnolv Vorren ${ }^{8}$ has summarized some points that are crucial for the acceptance of borders between Sáme Siida groups where both rivers and watersheds are the components that determine boundaries. ${ }^{8}$ The source for Vorren's reasoning is founded on Tegengren's comparison between hunting territories along the Yukon River and the Kemi Lappmark in Finland. ${ }^{7}$ The territory must in some way be determined, then made tangible and finally conveyed in such a way that allows people to move around within this abstraction. This may explain why settlements generally cluster at river junctions. The settlements might date from different epochs but the settlement pattern remains the same. Economic changes have not altered the fact that places where lines of communication cross are the most natural places to meet.

\section{Ethno-history as an analytic tool. watersheds and the taxation of the sáme}

The oldest historical sources with reference to Åsele Lappmark are from $1550 .{ }^{12}$ After 1650 the Swedish government began to levy a tax on Sami households. In order to do so they began to document 
and map Sámi settlements. The interesting thing to note is that the geographic location or address of any given household was often a specific lake (Sw. träsk or sjö Figure 2). Taxation occurred during the winter at which time households would have moved into a base camp or winter village located at a confluence. During the $17^{\text {th }}$ century the collection of taxes often occurred in conjunction with festivities paid for by the bailiff. ${ }^{12}$ It might be suspected that the time and place for the collection of this revenue was determined by longstanding and pre-existing local traditions and thus was a way by which the Royal Kingdom strove to appropriate this situation in order to assert its authority.

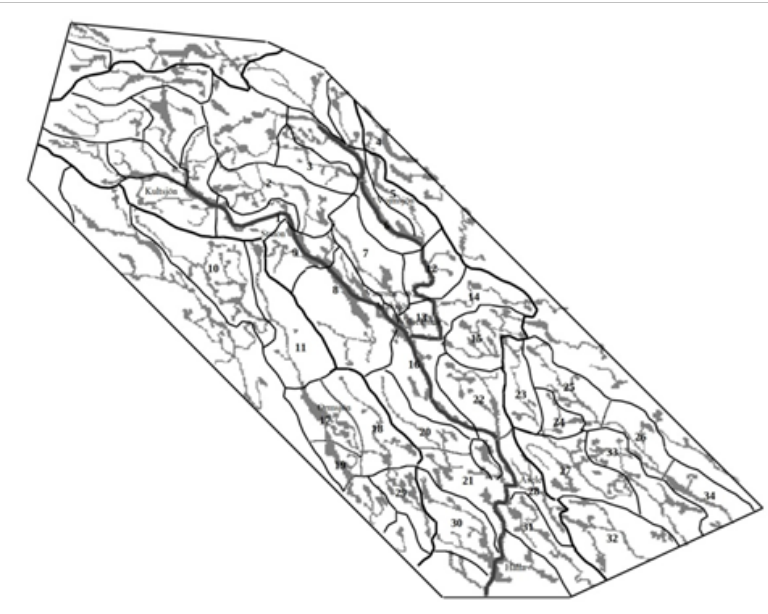

Figure 2 This subdivision of the Åsele Lappmark corresponds to a land unit that belonged to a household. The borders are determined by the watershed of a lake. The numbers refer to names noted from tax records dating to 1695 concerning the Sáme, with some additions from tax records of a later date (after Westerdahl 1986). Åsele Lappmark's principal river is the Ångermanälven and its entir watershed is marked on the map with a thick black line.

2. Östra Marsfiäll and Marsålandet

3. Gidofjäll

4. Långsiöö

5. Skikkensjö

6. Östra Volmsjölandet

7. Nästansjölandet

8. Östra Blajkfjällandet

9. Västra Malgomaj

10. Östra andVästra Arksjölandet

II. Kliekträsk andVästra Blajkfjäll

12. Grundsjölandet

13. Volgsjölandet

14. Bääksiöö

15. Järvsiöö, Mårdsjölandet

16. Amsele, Alsilla

17. Ormsiöö

It seems odd that the lakes are listed as the place of residence and not those areas where we have the largest accumulation of settlements, i.e. at the confluence of the rivers. One explanation could be that during this time fishing and reindeer herding were the main source of subsistence for the Sáme which resulted in a completely different location of the central places in comparison with that of the Stone and Bronze Age hunting gathering economy. In comparison the subsistence of the forest Sáme was different, as revealed by the tax records, in two main ways. First, the moose was almost extinct (Boethius et. al. 1975:21) and secondly, reindeer herding, despite its small scale, was now an important subsistence factor. Early records (1602) shows that each household between 11 and 28 reindeer. The länsman (title of the local chief of a Sáme group) Nils Tomasson had 40 reindeer, owned two lakes and the surrounding forest within a radius of $20 \mathrm{~km} .{ }^{13}$

References to lakes as a place of residence should probably not be understood as specifically refer to the lakes themselves, but as a way of denoting a unit of land. In fact the residence of a Sáme household was not only one specific lake but its entire watershed. This is evident from names with the suffix -land (Sw.-landet) such as Simsiöö Landet and Volmsiöö Landet.

This is also evident from an example were Pähr Jonasson Skum was acknowledged as owner over an area that encompassed the streams running into lake Avaträsk. In other words, the lake's entire watershed which corresponded to and coincided with recognized territorial ownership and its boundaries (Figure 2).

Åsele Lappmark has been divided into watershed areas which each cover about $500-600 \mathrm{~km}^{2}$. The size of these areas corresponds approximately to the size of a hunter gatherer territory in the boreal forest as well as to the size of a holding belonging to a Sáme household as indicated by the historical tax records from Åsele Lappmark. The Sáme land-tax (Sw. Lappskatteland) is an official and historical concept that refers to a unit of land that is owned by a Sáme household that is subjected to taxation. But the land unit as such has roots in prehistoric times. ${ }^{14,15}$ Hultblad's ${ }^{14}$ detailed reconstruction of the lappskatteland in the parish of Jokkmokk shows that land units can range from 100 to $700 \mathrm{~km}^{2} .{ }^{14}$ A reconstruction of the neighboring Umeå Lappmark (North of Åsele Lappmark) is more accurate, since a detailed map of the Sáme household land units was drawn up in 1671 . The land-units range from $148 \mathrm{~km}^{2}$ to $1000 \mathrm{~km}^{2}$, but the average size was $480 \mathrm{~km}^{2}$. Christer Westerdahl has made a simplified reconstruction of the land units in the Åsele Lappmark ${ }^{16}$ which helped to identify the location of those land units as depicted in Figure 2. However, the map should not be regarded as an attempt to reconstruct taxation units. Instead it is a generalized geographical breakdown to be used as a tool when evaluating the results of the spatial analysis of hunter gatherer economies. Thirty-six watershed areas have been identified that correspond relatively well with the 45 household units noted in the tax records of $1695 .{ }^{13}$ It should be noted that some of these land units mentioned in the historical records are located outside the study area and thus the map in Figure 2.

\section{Archaeological investigations in the åsele lappmark}

Figure 3 is an attempt to illustrate the archaeological investigations that have taken place in Assele Lappmark. Of course all of these investigations are not equivalent as concerns quantity or quality. The survey projects are relatively comprehensive and further work would not change the main picture though it would undoubtedly result in a larger amount of sites. For example, lake Avatäsk was surveyed 
by personnel from the Västerbotten Museum using both soil probes and shovels after a traditional survey using visual methods had been carried out. The number of sites increased from 1 to 60 . A similar result from lake Maksjön increased the number of sites fivefold. This was partly due to the fact that the accelerated erosion caused by the annual fluctuations of water levels brought on by the hydro-electric regulation of the lake has uncovered and is destroying, archeological sites in ever increasing numbers. ${ }^{17}$ There are various reasons for the discrepancies as concerns the results between the earliest and the latest archaeological surveys. ${ }^{18} \mathrm{Be}$ that as it may, it suffices to note that the surveys and excavations carried out by the Västerbotten museum when water levels were low yielded a surprising large number of new sites, features, materials and dates.

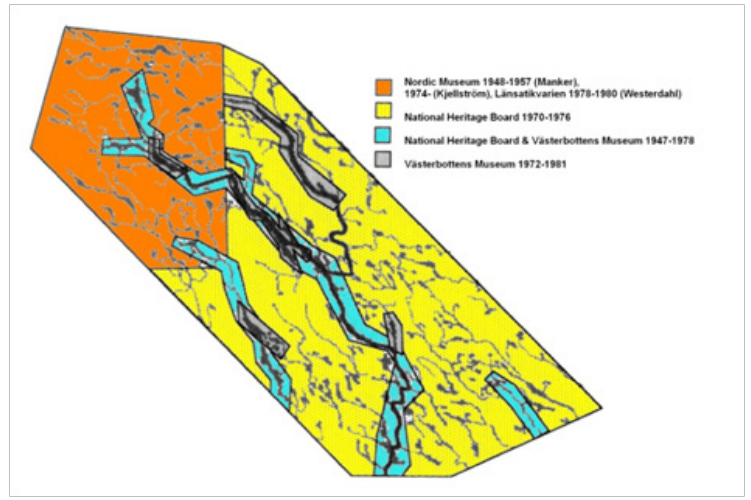

Figure 3 Archaeological investigations carried out in the area.

\section{Spatial analysis as an analytic tool: clusters of sites}

A large number of sites in any given area is often taken at face value and presented as verification of settlement intensity. ${ }^{19}$ But a cluster of a large number of sites does not necessarily represent a substantial deposit of features, artefacts and/or debitage resulting from intensive and/or long term settlement activities. Instead they only represent a large concentration of registered sites. I have here chosen to assume a more subjective assessment of where actual settlement concentrations are to be found. For this Lars Löthman's ${ }^{20}$ analysis was used as a starting point. The clusters presented here represent a subjective picture of where the most intensive settlement activities took place in prehistory. There are source-critical problems with this analysis. As noted above, different surveys employed different methods and the effects of erosion caused by water regulation have been mentioned, both which have relevance as concerns the number of sites discovered in any one given area.

The settlement clusters that we now see are located in and around the confluences where the major watersheds meet and flow into the principle waterway as represented by the Ångermanälven river (Figure 3). However, some exceptions may be noted. Around the present day community of Almsele on the Angermanälven river there is a concentration of sites but no inflow from any surrounding watersheds. The cluster of sites around the present day communities of Torvsjö and Dalsjö are both situated within their separate watersheds and somewhat removed from their respective confluence with the Ångermanälven river. However Torvsjö and Dalsjö are connected by an esker which suggests that they were important central places.

\section{Archaeology as an analytic tool}

In Figure 4 the most important features and artefacts of the archaeological record are classified and summarized. These elements represent seasonal activities and fall broadly into three chronological periods. This classification chart is a draft to illustrate the method and possibilities at hand. The oldest dates from the study area are from cooking pits and range between ca 8000-6000 BP. ${ }^{21}$ However, the context of these features is unclear and thus they have been excluded from this analysis. Features belonging to the following period 6000 to $4000 \mathrm{BP}$ are mainly the subterranean houses with a surrounding embankment of fire cracked stone (Sw. skävstensvallar). Smaller coking pits also occur during this time. Characteristic artefacts are slate tools ${ }^{3}$ with a dominance of quartz tools as compared to quartzite tools. Quartz workshops have been attributed to this period with some uncertainty.

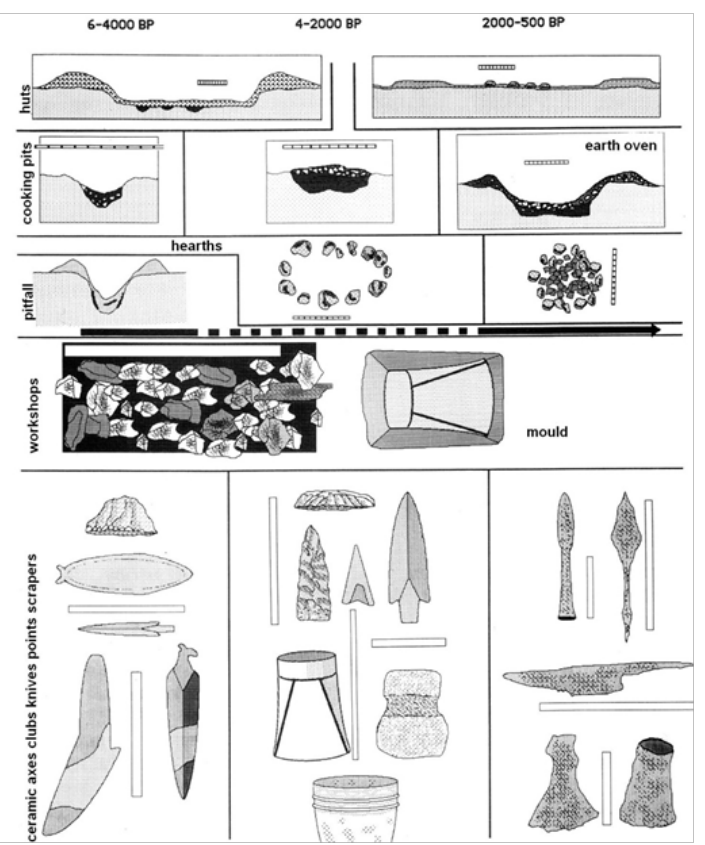

Figure 4 Classification scheme showing the chronology of the most important archaeological features and artefacts.

The third period ends about $2000 \mathrm{BP}$ and is characterized by an abundance of quartzite points and lithic workshops. Grooved clubs can also be ascribed to this period even though they do occur in other contexts. ${ }^{22}$ Nonetheless, they are here assumed to have been used during the Bronze Age. Asbestos ceramics occur during the latter part of the period. An older date has been obtained for the asbestos ceramics from Tärna parish (Laisan) and Norway. Thus theoretically the asbestos ceramics within the study area could also be older. However, the majority of dates available from Åsele Lappmark point to a younger context. ${ }^{23}$

Certain types of hearths and cooking pits can be attributed to this period. ${ }^{5}$ The retouch on scrapers from this time tends be longer than those from earlier periods..$^{24}$ Houses are poorly represented but could possibly be revealed through a more detailed analysis of the distribution of waste deposits across a site. ${ }^{25}$ The period after 2000 BP is represented by other types of features and artefacts although changes regarding tools and their functions during this period are not as yet well known. Points and knives are not found to the same extent as earlier. Scrapers cannot with certainty be assigned to this particular period. The features that belong to the period are small hearths, large earth ovens, some iron objects and artefacts from sacrificial places that stylistically can be attributed to the period. House foundations (Sw. stalotomter) are known only from the mountain region. ${ }^{26}$ The 
features that can be attributed to the period represent new functions and probably a more complicated system regarding trade and seasonal migration patterns than previously. Iron, of course, plays a role in this context. Iron production is not recorded in the study area but iron objects have been found, which of course must involve some kind of exchange and surplus production. The large earth ovens may be an indication of this since they represent a large-scale production of smoked meat or possibly skins. ${ }^{27}$

\section{Variations in the function of central places and the relationship to site clusters}

Applying the classification scheme (Figure 4) to the cluster image Figure 5 shows that the clusters belong to different periods and contexts.
Some of the defining criteria are included in the accompanying text to Figure 6. The quantitative distribution of sites, as mentioned above, is largely dependent on different types of archaeological investigations and methods that were used, the ramifications of which have not yet been adequately or critically assessed. However, some general trends may be noted. The clusters at lakes Varris and Kultsjön do not include subterranean houses and the cluster at the Gråtanån river does not include lithic workshops. Asbestos ceramics have not been found at the cluster around the Stalon area but occur instead on sites both upstream at lake Kultsjön and downstream at lake Varris. Larger systems of pitfalls are found along the Gråtanån river, at Dalasjö, at Hälla and at Åsele, but are noticeably less in number in the other areas. The large earth ovens are in many instances located close to pitfalls but are not directly linked with clusters of pitfalls.

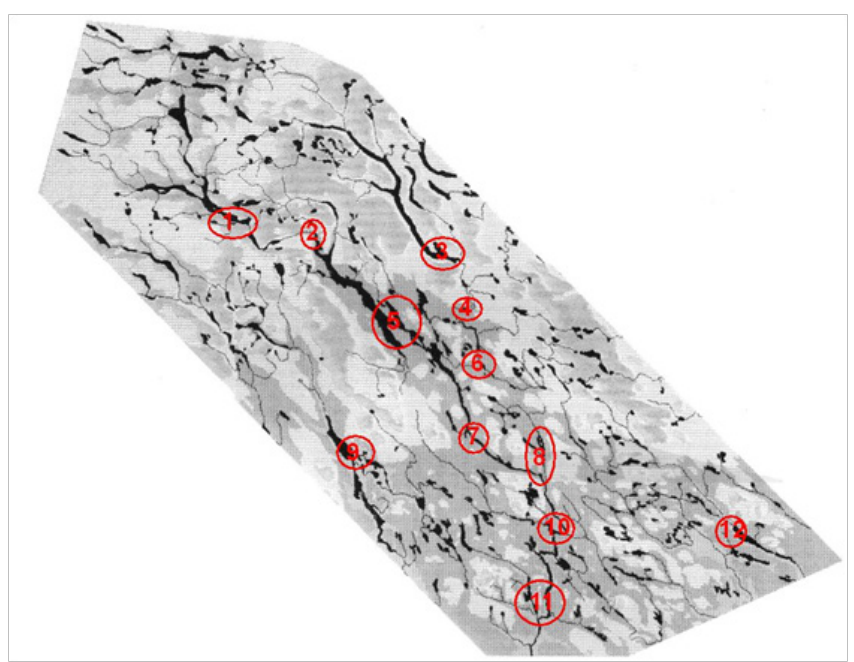

Figure 5 Clusters that primarily represent centers for a local band.

I. Kultsjön: Settlements with asbestos ceramics, points, clubs and sinkers. A major excavation was carried out in 1957 in connection with the exploitation of the water system for hydro-electric power.

2. Stalon: Settlements with II subterranean houses, a few pitfalls, a kiln, several lithic workshops and quarries. Several major excavations have been conducted here by the Västerbotten museum 1978-1980.

3. Gråtanån:About 30 settlements including 5 subterranean houses. Other remains within the area span from $8000 \mathrm{BP}$ to historical times.

4. Volgsele: Settlements, one with a subterranean house. Several pitfalls are known in the area. No excavation have been carried out.

5. Maksjön-Varris: Hundreds of settlements, workshops and quarries, but few house remains and pitfalls. Major excavations were conducted during the 1950 's by the National Heritage Board, but also after the regulation of the lakes by Västerbotten museum between 1972-1981. Dates range from about 7000 BP to historical times.

6. Dalasjö:About 10 settlements are known, several with subterranean houses. Ninety pitfalls have been recorded and some have been excavated.

7. Almsele-Råsele:About 70 settlements of which 4 were excavated and nearly 30 were investigated prior to the regulation of the water system in the 1970's. Some pitfalls are also recorded.

8. Torvsjön: Nearly 60 settlements are located around the lake, all of which are situated within the erosion zone. At the outlet of lake Torvsjö into the Ångermanälven river there are 3 subterranean houses, one which was excavated in connection with the exploitation of the water system for hydro-electric power. One cooking pit with quartz debitage was dated to about 8000 BP.

9. Ormsjön:About 70 settlements, some which were investigated by the National Heritage Board in

10. Connection with the exploitation of the water system for hydro-electric power during the 1950's. Later two major excavations were conducted by the Västerbotten museum. The majority of the material appears to be from the Bronze Age, consisting as it does of a large amount of quartzite and ceramics. But the area should be seen as part of a larger complex with lake Hoting as its center (outside the map) where nearly 200 settlements are known.

1I. Åsele:About 60 settlements and 255 pitfalls are known in this area. Two settlements were investigated in connection with the exploitation of the water system for hydro-electric power during thel 970 's.

12. Hälla: Sixty five settlements and over 30 pitfalls are recorded. Excavations have been carried out by a number of institutions between 1958 and 1977. Several dates are available from both settlements and pitfalls, but none are older than approximately $4000 \mathrm{BP}$.

13. An area with both settlements and pitfalls. Not investigated. 


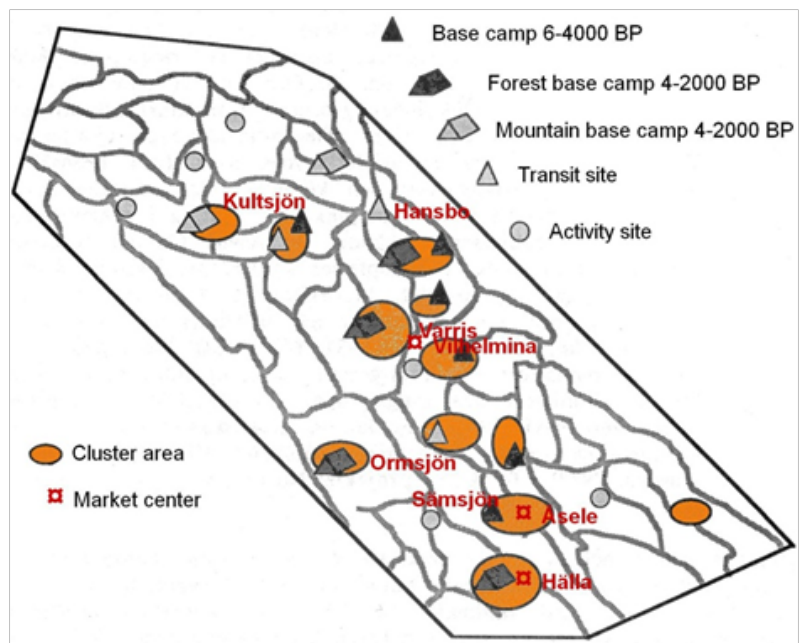

Figure 6 The relationship between clusters and various centers.

In general terms, it is possible to estimate some changes concerning the functions of the central places to changing subsistence and migratory strategies or systems. Forsberg' $\mathrm{s}^{25}$ models have been applied to the cluster image in order to obtain a theoretical starting point. 8-6000 BP: The oldest dates occur in most of clusters. However these dates are not few in number and thus not enough to formulate an impression concerning the type nor may extent of the socio-economic network of contacts have then existed.

6-4000 BP: The period is distinguished by a regular distribution of clusters comprised of subterranean houses. Lundberg has interpreted this pattern as an indication that there existed a division of land between bands. Each band held an area of ca $35 \mathrm{~km}$ in diameter or about $1000 \mathrm{~km}^{2}$. Finds of contemporary slate tools suggest that the area around lake Varris was commonly used by a band during the summer months. ${ }^{3}$ The population of the Varris band is estimated to have consisted of about 75 people divided into 15 households. This is a relatively low population for a self-sufficient group and they probably had contacts with other bands. The Almsele- Råsele area could be a corresponding meeting place similar to the Varris area, but with its connections downstream along the river Angermanälven to areas outside of the Åsele Lappmark. Such a system implies that centers, meeting places, alternate annually and/or seasonally. However, features and artefacts from the Almsele-Råsele area indicate that these sites belong to younger period (Figure 5).

4-2000 BP: Forsberg ${ }^{25}$ argues that settlements with asbestos ceramics and scrapers are characteristic of base camps in the forest areas, while a combination of points and ceramics characterizes base camps in the mountain areas. Transit sites also have ceramics. For this period, a large number of sites are located outside the clusters. For example Hansbo which is most likely to be comparable to a transit site. ${ }^{28}$ Settlements around lake Kultsjön are also from this period and comparable to Forsberg's mountain base camps. Forest base camps are found, for example, around the lake Varris area. On these sites stone clubs and molds for the casting of bronze objects are frequent.

Forsberg proposes that Norrfors on the river Umeälven and Nelkirim on the river Lilla Luleälven were central places due to the rich availability of salmon at these places during summer. The corresponding central place for the different groups in the Ångermanälven river system could be Nämforsen. ${ }^{25} \mathrm{~A}$ central place located between groups moving towards the mountains and those moving towards the coast must have existed in order to hold them together. The rock art site at lake Sämsjön is interesting in this perspective. The site is located close to the watershed between lake Ormsjön and the river Ångermanälven and could have been a meeting place for groups residing in neighboring river valleys. 2000-500 BP: This period has not been dealt with in detail. Field surveys show that features and artefacts belonging to this period are found at the clusters although none of the earth ovens, pitfalls and small hearths has yet been dated. In addition, hearths were not a priority during the archaeological surveys and consequently Iron Age and medieval Sáme settlements are not well known. ${ }^{29}$ Inger Zachrisson point out other factors that have resulted under representation of Sáme sites from this period. ${ }^{19}$

The use of earth ovens may have been a seasonal activity in contrast to the smaller cooking pits. Earth ovens are located close to pitfalls which suggest that both features were in use during the winter. Perhaps, as reindeer herding developed, households became more sedentary during this period and more geographically bound to an area around a lake. Contacts and networks were maintained as described in historical sources, with annual gatherings of 10-15 households during festivities. These places later became market centers, for example Åsele and Vilhelmina. Gulsele, which lies within the cluster at Hälla, was also a market place before $1605 ., 30-37$

\section{Acknowledgements}

With this essay, I owe thanks for the good advice, especially to Prof. Evert Baudou, my supervisor, and the Center for Arctic Cultural Research, especially Dr. Roger Kvist, for assistance with historical sources. I also wish to thank Dr. David Loeffler for his encouragement and for the translation to English.

\section{Conflict of interest}

Author declares there is no conflict of interest in publishing the article.

\section{References}

1. Wik B. Sentrum - periferi: Sentra og sentrumdannelse gjenom förhistoriskog historisk tid. Universitetet i Trondheim, 1991. p. 455

2. Käck J. Samlingsboplatser? En diskussion om människors möten i norr 7000 f Kr Kr f med särskild utgångspunkt i data från Ställverksboplatsen vid Nämforsen. Studia Archaeologica Universitatis Umensis 24, Sweden; 2009. p. 225.

3. Lundberg Å. Skärvstensvallar i Norrland. Studier i Norrländsk forntid II. Acta Bothniensia Occidentalis, Skrifter i västerbottnisk kulturhistoria 8 Sweden; 1986. p. 81-99.

4. Forsberg L. Site variability and settlement patterns. Archaeology and Environment 5, University of Umea, Sweden; 1985.

5. Price TD. A proposed model for procurement systems in the mesolithic of Northwestern Europe. In: E Koslowski, editor. The mesolithic in Europe Papers read at the International symposium on the Mesolithic in Europe 1972. Warsava Spång L G Västerbotten. 1973;2:66-74.

6. Damas D. Contributions to Anthropology: Band Societies. Bulletin of the National Museum of Canada 228, Canada; 1969.

7. Tegengren H. En utdöd lappkultur i Kemi lappmark. Studier i Nordfinlands kolonisationshistoria, Acta Academia Aboensis Humaniora XIX, Åbo akademi, Finland; 1952.

8. Vorren Ø. Samisk bosetning på nordkalotten, arealdisponering og ressursutnytting i historisk-økologisk belysning. Nord-Skandinaviens historia i tvärvetenskaplig belysning. Acta Universitas Umensis, Sweden; 1980 . 
9. Anderson A. Economic change and the prehistoric fur trade in northern Sweden: The relevance of a Canadian model. Norwegian archaeological review. 1981;14(7):1-16.

10. Shea JO. Coping with scarcity: Exchange and social storage. In: Sheridan A \& Bailey G, editors. Economic archaeology towards an integration of ecological and social approaches, BAR international series. 1981;96:167-186.

11. Madden M. Social network systems amongst hunter-gatherers considered within southern Norway. In: Bailey G, editor. Hunter-gatherer economy in prehistory. A European perspective, New directions in archaeology. Cambridge; 1983. p. 191-200.

12. Lundmark L. Så länge vi har marker - samerna och staten under sexhundra år. Raben Prisma, Sweden; 1998. p. 143.

13. Gustavsson G. Ångermanlands lappmark. Ångermanland 1979; $14: 104-212$.

14. Hultblad F. Övergång från nomadism till agrar bosättning i Jokkmokks socken. Acta lapponica XIV, Nordiska museet, Sweden; 1968.

15. Arell N. Rennomadismen $i$ Torne lappmark. Kungliga skytteanska samfundets handlingar 17, Sweden; 1977. p. 336.

16. Westerdahl C. Samer nolaskogs. En historisk introduktion till samerna i Ångermanland och Åsele lappmark. CEWE-förlaget, Sweden; 1986.

17. Meschke C. Underlagsmaterial för bostadsdepartementets utredning om överledning för vattenkraftändamål av vatten från Piteälven och Vindelälven. Kulturlandskap i älvdalar III, Riksantikvarieämbetet och statens historiska museer rapport, Sweden; 1979. p. 256.

18. Loeffler D. Contested landscapes/contested heritage: history and heritage in Sweden and their archaeological implications concerning the interpretation of the Norrlandian past. Archaeology and environment Arkeologi och samiska studier. Sweden; 2005. p. 253

19. Zachrisson I. Arkeologi och etnicitet: Samisk kultur i mellersta Sverige ca 1 -1500e Kr. Bebyggelsehistorisk tidskrift 1987;14:24-41.

20. Löthman L. Skärvstensanläggningar i södra Lappland. Studier i Norrländsk forntid II. Acta Bothniensia Occidentalis. Skrifter västerbottnisk kulturhistoria 8. Sweden; 1986. p. 7-46.

21. Sundlin H. Gammal datering från Åsele. Studier i Norrländsk forntid II, Acta Bothniensia Occidentalis, Skrifter i västerbottnisk kulturhistoria 8, Sweden; 1986. p. 132-136.

22. Indreko R. Steingeräte mit Rille. KVHAA handlingar, antikvariska serien 4, Almqvist,Wiksell, Sweden; 1956. p. 162.
23. Jørgensen R \& Olsen B. Asbestkeramiske grupper i Nord-Norge 2100 f.Kr - 100 e.Kr. Tromura, Kulturhistoria nr.13. Tromsö. 1988.

24. Spång LG. Stenåldersbostaden: Studier i Norrländsk forntid II. Acta Bothniensia Occidentalis, Skrifter i västerbottnisk kulturhistoria 8, Sweden; 1986. p. 47-80.

25. Forsberg L. Bosättningsmönster vid Lule och Ume älv under bronsålder och förromersk järnålder. Arkeologi i nor. 1988;1:51-102.

26. Kjellström R. Staloproblemet i samisk historia: Folk og resurser i nord Foredrag fra Trondheims-symposiet om midt- og nordskandinavisk kultur, Trondheim. 1983. p. 213-235.

27. Melander J. Torkugnar. Studier i Norrländsk forntid II. Acta Bothniensia Occidentalis, Skrifter i västerbottnisk kulturhistoria 8, Sweden; 1986. p. $119-125$.

28. Walukiewich U. Rapport över arkeologisk undersökning av stenåldersboplats. Vuollerim 6000 år, Sweden; 1983.

29. Bergman I. Det samiska boplatskomplexet vid Rackträsk, Arjeplog. Arkeologi i norr. 1988;1:129-143.

30. Bergling R. Kyrkstaden i övre Norrland. Skytteanska samfundets handlingar 3. Sweden; 1964.

31. Barceló J A, Del Castillo F. Simulating Prehistoric and Ancient Worlds. Springer International Publishing, Sweden; 2016.

32. Cummings V, Jordan P, Zvelebil M. The Oxford Handbook of the Archaeology and Anthropology of Hunter-Gatherers. Oxford University Press, UK; 2014.

33. Hvarfner H. Endast före eller även under järnåldern. Om det norrländska inlandets stenålderskultur. Västerbotten; 1957. p. 70-155.

34. Jennes D. Indians of Canada, $5^{\text {th }}$ ed. Bulletin 65 Anthropological series, National Museum of Canada, Sweden; 1932.

35. Manker E. Fångstgropar och stalotomter: Kulturlämningar efter lappsk forntid. Acta Lapponica XV, Geber, Sweden; 1960.

36. Robert Whallon. Social networks and information: Non-"utilitarian" mobility among hunter-gatherers. Journal of Anthropological Archaeology. 2006;25(2):259-270.

37. Zachrisson I. Lapps and Scandinavians. Archaeological finds from northern Sweden. Early Norrland 10, Stockholm, Sweden; 1976. p. $130-136$. 